Postgate, J. R. (1952). J. gen. Microbiol. 6, 128-142

\title{
Competitive and Non-competitive Inhibitors of Bacterial Sulphate Reduction
}

\author{
By J. R. POSTGATE \\ Chemical Research Laboratory, Teddington, Middlesex
}

SUMMARY: The selenate ion, a remarkably powerful competitive antagonist of the reduction of sulphate by Desulphovibrio desulphuricans (Hildenborough) suspensions, did not affect reduction of sulphite and thiosulphate. Cysteine, methionine and glutathione had no anti-selenate effect. Selenate also inhibited the growth of D. desulphuricans; this effect was antagonized competitively by sulphate and noncompetitively by sulphite. Repeated subculture in subinhibitory selenate + sulphate mixtures did not give rise to a selenate-resistant strain, though selenium was deposited in these conditions.

The monofluorophosphate ion behaved similarly: it was a competitive sulphate antagonist in growth and in sulphate reduction, though it had a lower specific antisulphate activity than selenate. It did not affect the metabolism of sulphite or thiosulphate. At high concentrations it showed non-competitive inhibition of sulphate reduction.

Of the other 'analogues' of sulphate tested, potassium tellurate suspensions and chromate inhibited growth and sulphate reduction, but were not competitive sulphate antagonists. High concentrations of perchlorate depressed sulphate reduction in a non-competitive manner, and methanesulphonate, $\beta$-hydroxyethanesulphonate, benzenesulphonate, ethylsulphate, sulphamate and dimethylsulphone were inactive.

An acridinium dye known to inhibit the growth of $D$. desulphuricans did not affect sulphate reduction, and, in growth, was not antagonized by sulphate or complex nitrogenous supplements. 'The organism was readily 'trained' to resist this dye.

The control of the growth and metabolic activities of Desulphovibrio desulphuricans is a problem of practical as well as of theoretical interest, in view of their role both in the anaerobic corrosion of ferrous pipes (von Wolzogen Kuhr \& van der Vlugt, 1934; Bunker, 1936, 1939; Hadley, 1943; Rogers, 1940, 1945 ; Starkey \& Wight, 1945; Starkey, 1947; Butlin \& Vernon, 1949; Chemistry Research, 1938-46, 1947, 1948, 1949) and in the pollution of water and sewage (Bunker, 1942; Rogers, 1945; Allen, 1949; Butlin, 1949). Hence the inhibition of these bacteria has been studied largely from a practical standpoint. Rogers (1940) investigated the resistance of crude cultures to various dyestuffs and observed that acriflavine and proflavine were their most active inhibitors. $\mathrm{He}$ studied in detail a dye of the acridinium group, '914', and showed that its activity depended on inoculum size. He noted the possibility that adaptation to resist the dyestuff could take place, and a further publication (Rogers, 1945) described the practical use of the dye. Bunker (1942) advocated decrease of $\mathrm{pH}$ value to control the pollution of relatively small water volumes by sulphate reducers. Allen (1949) confirmed this in a study of their activities in sewage, mentioned their high resistance to chlorine and showed that various nitro-compounds depressed $\mathrm{H}_{2} \mathrm{~S}$ formation. The resistance of these organisms 
to many common inhibitors and antibiotics has been studied (Chemistry Research, 1947, 1948, 1949), and an effect of ferrous ions in enhancing this resistance was mentioned (Chemistry Research, 1947). This effect could be partly due to differences between the methods used to detect growth in these experiments: blackening of the culture by ferrous sulphide formation can occur at levels of growth undetectable by direct inspection. Postgate (1949) described the competitive inhibition of sodium sulphate reduction by sodium selenate, using a non-growing cell suspension, and showed that sulphite overcame the consequent inhibition of hydrogen absorption in a non-competitive manner. The competitive inhibition of growth by selenate has been briefly reported, together with the failure of selenate to influence the reduction of thiosulphate and with manometric tests of selenite, tellurite and tellurate (Chemistry Research, 1949).

Fels \& Cheldelin (1949b) showed that sodium sulphate overcame the inhibition of yeast growth by selenate in a competitive manner; with their organism methionine had some anti-selenate effect, though cysteine and glutathione had none (Fels \& Cheldelin, 1948). In contrast, methionine had no anti-selenate effect for Escherichia coli, though cysteine and glutathione were active (Fels \& Cheldelin, 1949a). Earlier studies by Hurd-Karrer (1937, 1938) on the selenate inhibition of growth of wheat plants showed that the effect of selenate depended on the amount of sulphate present, and that a molar proportion of selenate to sulphate considerably less than 1:1 prevented growth. She demonstrated that, at subinhibitory selenate levels, selenium was incorporated into the plant tissue in the same ratio to sulphur as in the nutrient solution provided.

The discovery of the anti-sulphate activity of selenate for $\boldsymbol{D}$. desulphuricans led to a further investigation of this effect, together with a study of other sulphate analogues and some tests on the acridinium dye ' 914 '. The results are reported here.

\section{METHODS}

Organism. A strain of $\boldsymbol{D}$. desulphuricans called 'Hildenborough' was used throughout this work; its origin, maintenance and methods of subculture were described by Postgate (1951 $a$ ).

Media. A medium (A) of: Bacto-tryptone (Difco) 5 g.; yeast extract (Difco) 4 g.; glucose 10 g.; $\mathrm{MgSO}_{4} .7 \mathrm{H}_{2} \mathrm{O} 1.5 \mathrm{~g}$.; $\mathrm{Na}_{2} \mathrm{SO}_{4} 1.5 \mathrm{~g}$.; in 11 . distilled water at $\mathrm{pH} \mathbf{7 \cdot 2} \pm \mathbf{0 \cdot 2}$, was used to grow organisms for manometric work and for routine subculture. For growth experiments requiring media of known sulphate content a sulphate-deficient modification of this medium was used (medium B): $\mathrm{Na}_{2} \mathrm{SO}_{4}$ was omitted and $\mathrm{MgSO}_{4} \cdot 7 \mathrm{H}_{2} \mathrm{O}$ was replaced by $\mathrm{MgCl}_{2}$. $6 \mathrm{H}_{2} \mathrm{O}$ at $0.8 \mathrm{~g}$./l. (Postgate, $1951 \mathrm{~b}$ ). Reagents were 'Analar' grade throughout except where mentioned in the text. The media containing glucose were sterilized by steaming for $1 \mathrm{hr}$. on three successive days; test solutions were autoclaved at $15 \mathrm{lb}$./sq.in. for $15 \mathrm{~min}$. except for sodium sulphite, sodium thiosulphate and potassium chromate, which were sterilized by Seitz filtration. Potassium tellurate suspensions were not sterilized (below, p. 138). 
Resting cell suspensions. Cell suspensions of 1-3 mg. dry wt./ml. in $0.8 \%$ $\mathrm{NaCl}$ were prepared and, after pre-incubation in a stream of $\mathrm{H}_{2}$ to remove traces of sulphate, $1 \mathrm{ml}$. portions were used in $2.5 \mathrm{ml}$. of liquid in the Warburg manometer at $\mathrm{pH} 6.3$ as described by Postgate (1951b); cadmium chloride was used in the centre cup to absorb sulphide.

Growth tests. The effect of inhibitors on growth was studied by the conventional method of inoculating tubes of medium $\mathbf{B}$ containing a range of inhibitor concentrations and known amounts of $\mathrm{Na}_{2} \mathrm{SO}_{4}$. Media free of added iron were used since ferrous ions are known to alter the apparent sensitivity of sulphate-reducing bacteria to inhibitors.

Sulphate estimations. In one part of the work reported here the sulphate content of Warburg manometer suspensions was estimated turbidimetrically, after removal of bacteria, by treatment of $1 \mathrm{ml}$. of solution with $5 \mathrm{ml}$. of $\mathrm{BaCl}_{2}$ $(1 \% \mathrm{w} / \mathrm{v}$ in $0 \cdot 1 \mathrm{~N}-\mathrm{HCl}$ ) and diluting to $10 \mathrm{ml}$. final volume. This method was shown to estimate between $10^{-7}$ and $7 \times 10^{-7} \mathrm{~mol} \mathrm{Na}_{2} \mathrm{SO}_{4}$ with no perceptible deviation among six tests, provided the precipitate was tested within $15 \mathrm{~min}$. of preparation and provided the method was used only for the centrifuged residues of manometric experiments (below, p. 131).

\section{RESULTS}

\section{Sodium selenate}

The inhibition of sulphate reduction by selenate and the effect of sulphite have already been described (Postgate, 1949). In manometer vessels containing high concentrations of $\mathrm{Na}_{2} \mathrm{SO}_{4}$ and $\mathrm{Na}_{2} \mathrm{SeO}_{4}$ (British Drug Houses Ltd.) at a subinhibitory concentration ratio a red precipitate of selenium was found at the end of the experiment, the amount depending on the amount of selenate added.

Methionine, cysteine and glutathione, known to be anti-selenate substances for yeast and Esch. coli (Fels \& Cheldelin, 1948, 1949a,b), were tested in the manometer at $1 \mathrm{mg} . / \mathrm{ml}$. as anti-selenate substances for $D$. desulphuricans. They did not affect the rate of sulphate reduction by partially inhibited cells (Table 1).

Table 1. Hydrogen absorption by cell suspensions of D. desulphuricans (Hildenborough); test of various possible anti-selenate compounds

Vessels contained $2.5 \mathrm{ml}$. of fluid at $37^{\circ} \mathrm{C}$.

\begin{tabular}{|c|c|c|c|c|}
\hline $\begin{array}{c}\mathrm{Na}_{2} \mathrm{SO}_{4} \\
\text { (mol.) }\end{array}$ & $\begin{array}{c}\mathrm{Na}_{2} \mathrm{SeO}_{4} \\
\text { (mol.) }\end{array}$ & $\begin{array}{c}\text { Test } \\
\text { substance } \\
\text { (1 mg.) }\end{array}$ & $\begin{array}{c}\text { Dry wt. } \\
\text { of cells } \\
\text { (mg.) }\end{array}$ & $\begin{array}{c}-Q_{\mathrm{H}_{2}} \\
(\mathrm{~mm} \cdot \mathrm{s} / \mathrm{mg} \cdot / \mathrm{hr} .)\end{array}$ \\
\hline $5 \times 10^{-6}$ & - & - & 0.74 & 361 \\
\hline $5 \times 10^{-6}$ & $10^{-7}$ & - & 0.74 & 108 \\
\hline $5 \times 10^{-6}$ & $10^{-7}$ & Methionine & 0.74 & 100 \\
\hline $5 \times 10^{-6}$ & $10^{-7}$ & Glutathione & 0.74 & 99 \\
\hline - & - & - & $0 \cdot 74$ & 19 \\
\hline \multicolumn{5}{|c|}{ Another series: } \\
\hline $5 \times 10^{-6}$ & - & - & $1 \cdot 18$ & 530 \\
\hline $5 \times 10^{-6}$ & $10^{-7}$ & - & $1 \cdot 18$ & $84 \cdot 5$ \\
\hline $5 \times 10^{-6}$ & $10^{-7}$ & Cysteine & $1 \cdot 18$ & $86 \cdot 5$ \\
\hline- & - & - & $1 \cdot 18$ & 16 \\
\hline
\end{tabular}


The inhibition of hydrogen absorption by $\mathrm{Na}_{2} \mathrm{SeO}_{4}$ was overcome in a noncompetitive manner by sodium sulphite, though preliminary experiments (Postgate, 1949) indicated that the reduction of $\mathrm{Na}_{2} \mathrm{SO}_{3}$ was in these circumstances incomplete. This finding suggested that selenate could block sulphate reduction at a second stage en route to sulphide. During this incomplete $\mathrm{Na}_{2} \mathrm{SO}_{3}$ reduction, however, sulphide was formed, and this observation was explained by the discovery of $\mathrm{Na}_{2} \mathrm{SO}_{4}$ as impurity in 'Analar' grade $\mathrm{Na}_{2} \mathrm{SO}_{3}$, the reduction of which was blocked by the $\mathrm{Na}_{2} \mathrm{SeO}_{4}$. The molecular weight of $\mathrm{Na}_{2} \mathrm{SO}_{3} \cdot 7 \mathrm{H}_{2} \mathrm{O}$ (252) is fairly close to three-quarters of that of $\mathrm{Na}_{2} \mathrm{SO}_{4} \cdot 10 \mathrm{H}_{2} \mathrm{O}(322)$, and since sulphite reduction absorbed $3 \mathrm{~mol} . \mathrm{H}_{2} /$ ion and sulphate reduction $4 \mathrm{~mol} . \mathrm{H}_{2} / \mathrm{ion}$, the presence of considerable amounts of hydrated $\mathrm{Na}_{2} \mathrm{SO}_{4}$ impurity remained undetected in manometric tests with $\mathrm{Na}_{2} \mathrm{SO}_{3}$ alone. 'Analar' grade $\mathrm{Na}_{2} \mathrm{SO}_{3}$ contained from 4 mol. $\%$ of $\mathrm{Na}_{2} \mathrm{SO}_{4}$ to as much as $75 \mathrm{~mol} . \%$ of $\mathrm{Na}_{2} \mathrm{SO}_{4}$ in an old specimen; the sulphate could be removed by recrystallization of the less heavily contaminated batches.

Using pure $\mathrm{Na}_{2} \mathrm{SO}_{3}$ in the presence of $\mathrm{Na}_{2} \mathrm{SeO}_{4}, 3 \mathrm{~mol} . \mathrm{H}_{2}$ were shown to be absorbed $/ \mathrm{SO}_{3}{ }^{\prime \prime}$ ion reduced, and $1 \mathrm{~mol}$. sulphide was found by iodometric analysis in the centre manometer cup (Postgate, $1951 \mathrm{~b}$ ). Results of an experiment demonstrating the complete reduction of $\mathrm{Na}_{2} \mathrm{SO}_{3}$ in the presence of concentrations of $\mathrm{Na}_{2} \mathrm{SeO}_{4}$ which inhibited $\mathrm{Na}_{2} \mathrm{SO}_{4}$ reduction are given in Table 2. A specimen of $\mathrm{Na}_{2} \mathrm{SO}_{3}$ contaminated with $30 \mathrm{~mol}$. \% of $\mathrm{Na}_{2} \mathrm{SO}_{4}$ was used, and the $\mathrm{Na}_{2} \mathrm{SO}_{4}$ remaining at the end of the experiment was found by centrifuging the suspension and estimating the sulphate turbidimetrically as $\mathrm{BaSO}_{4}$. Controls were included to ensure that precipitation of $\mathrm{BaSeO}_{4}$ did not interfere at the concentrations used.

Table 2. Reduction of impure $\mathrm{Na}_{2} \mathrm{SO}_{3}$ (containing 30 mol. $\% \mathrm{Na}_{2} \mathrm{SO}_{4}$ ) in the presence of $\mathrm{Na}_{2} \mathrm{SeO}_{4}$ by $\mathrm{D}$. desulphuricans (Hildenborough)

Vessels contained $2.5 \mathrm{ml}$. fluid at $37^{\circ}$ and $2.84 \mathrm{mg}$. dry wt. cells.

\begin{tabular}{|c|c|}
\hline \multicolumn{2}{|c|}{$\begin{array}{l}\text { Contents of vessel } \\
\left(\mathrm{mol} \times 10^{-6}\right)\end{array}$} \\
\hline $\mathrm{Na}_{2} \mathrm{SO}_{3}$ & $\mathrm{Na}_{2} \mathrm{SeO}_{4}$ \\
\hline 2.5 & 一 \\
\hline $2 \cdot 5$ & 5 \\
\hline- & 5 \\
\hline
\end{tabular}

Amount of
$\mathrm{H}_{2}$ absorbed
(mol. \%
theoretical)
$\mathbf{9 7}$
$\mathbf{5 7}$
(Trace)

Amount of
ulphide formed
(mol. \%
theoretical)
96
63
0

Amount of
sulphate
remaining
$\left(\right.$ mol. $\%$ of $\left.^{\circ} \mathrm{Na}_{2}\right)$
$\mathbf{0}$
$\mathbf{3 7}$
0

The reduction of sodium thiosulphate took place in the presence of $\mathrm{Na}_{2} \mathrm{SeO}_{4}$ concentrations which were able to prevent the reduction of ten times the molar concentration of $\mathrm{Na}_{2} \mathrm{SO}_{4}$. A cell suspension of $1.0 \mathrm{mg}$. dry wt.

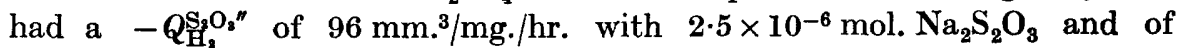
$84 \mathrm{~mm} .3 / \mathrm{mg}$. $/ \mathrm{hr}$. with $2.5 \times 10^{-6} \mathrm{~mol}$. $\mathrm{Na}_{2} \mathrm{~S}_{2} \mathrm{O}_{3}+2.5 \times 10^{-6} \mathrm{~mol} \mathrm{Na}_{2} \mathrm{SeO}_{4}$. In manometric experiments using $\mathrm{Na}_{2} \mathrm{SO}_{3} / \mathrm{Na}_{2} \mathrm{SeO}_{4}$ and $\mathrm{Na}_{2} \mathrm{~S}_{2} \mathrm{O}_{3} / \mathrm{Na}_{2} \mathrm{SeO}_{4}$ mixtures, controls containing these mixtures and buffer without bacteria were included. After 90 min. incubation they were estimated for $\mathrm{Na}_{2} \mathrm{SO}_{3}$ or $\mathrm{Na}_{2} \mathrm{~S}_{2} \mathrm{O}_{3}$ iodometrically, and no losses of these compounds were detected. Thus there 
was no chemical reaction between selenate and the test materials at $\mathrm{pH} 6.3$ and $37^{\circ}$.

Growth in medium $\mathrm{B}$ with $10^{-2} \mathrm{M}-\mathrm{Na}_{2} \mathrm{SO}_{4}$ was optimal, but a concentration of $10^{-1} \mathrm{M}-\mathrm{Na}_{2} \mathrm{SO}_{4}$ depressed growth (Postgate, $1951 \mathrm{~b}$ ). It was therefore undesirable to test the effect of $\mathrm{Na}_{2} \mathrm{SeO}_{4}$ on growth over a wide range of $\mathrm{Na}_{2} \mathrm{SO}_{4}$ concentrations, lest the depression of growth by strong $\mathrm{Na}_{2} \mathrm{SO}_{4}$ solutions should interfere with quantitative comparisons. Preliminary experiments showed that $\mathrm{Na}_{2} \mathrm{SeO}_{4}$ inhibited growth, and that at subinhibitory $\mathrm{Na}_{2} \mathrm{SeO}_{4}$ levels a red precipitate of selenium was formed. This precipitate interfered with accurate turbidimetric comparisons between cultures, but the tests gave an adequate indication that $\mathrm{Na}_{2} \mathrm{SeO}_{4}$ acted as a competitive $\mathrm{Na}_{2} \mathrm{SO}_{4}$ antagonist over a fivefold concentration range (Table 3). The molar $\mathrm{Na}_{2} \mathrm{SeO}_{4}$ : $\mathrm{Na}_{2} \mathrm{SO}_{4}$ ratio required to prevent visible growth lay between $1: 10$ and $1: 20$, consistent with a ratio of between 1:10 and 1:15 found in manometric studies (Postgate, 1949).

Table 3. Selenate-sulphate and selenate-sulphite antagonisms in growth of D. desulphuricans (Hildenborough) in medium $B$

Cultures ( $5 \mathrm{ml}$.) were incubated for $120 \mathrm{hr}$. and then inspected.

\begin{tabular}{|c|c|c|}
\hline $\begin{array}{c}\mathrm{Na}_{2} \mathrm{SO}_{4} \text { conc. } \\
(M)\end{array}$ & $\begin{array}{l}\text { Least conc. } \\
\text { of } \mathrm{Na}_{2} \mathrm{SeO}_{4} \\
\text { preventing } \\
\text { growth (M) }\end{array}$ & $\begin{array}{l}\text { Greatest conc. } \\
\text { of } \mathrm{Na}_{2} \mathrm{SeO}_{4} \\
\text { permitting } \\
\text { growth (M) }\end{array}$ \\
\hline $\begin{array}{c}10^{-2} \\
2 \times 10^{-2} \\
5 \times 10^{-2}\end{array}$ & $\begin{array}{c}2 \times 10^{-3} \\
4 \times 10^{-3} \\
10^{-2}\end{array}$ & $\begin{array}{c}10^{-3} \\
2 \times 10^{-3} \\
5 \times 10^{-3}\end{array}$ \\
\hline$\underset{10^{-2}}{\mathrm{Na}_{2} \mathrm{SO}_{3} \text { conc. }(\mathrm{M})}$ & $>2 \times 10^{-2}$ & $>2 \times 10^{-2}$ \\
\hline
\end{tabular}

Table 3 also records that $\mathrm{Na}_{2} \mathrm{SO}_{3}$ acted as a non-competitive selenate antagonist in the growth of $D$. desulphuricans. Growth with $10^{-2} \mathrm{M}^{-\mathrm{Na}_{2}} \mathrm{SO}_{3}$ occurred with $\mathrm{Na}_{2} \mathrm{SO}_{3}: \mathrm{Na}_{2} \mathrm{SeO}_{4}$ ratios from $10: 1$ to $1: 2$, above which they were not tested. The presence of $\mathrm{Na}_{2} \mathrm{SeO}_{4}$ decreased the rate and extent of growth at all ratios, the cultures containing $\mathrm{Na}_{2} \mathrm{SeO}_{4}$ growing about $24 \mathrm{hr}$. later than the controls and to about half the extent. Useful quantitative measurements of this effect could not be obtained owing to a precipitate of selenium which appeared in the cultures once the logarithmic phase of growth had started. Controls containing $\mathrm{Na}_{2} \mathrm{SO}_{3}$ and $\mathrm{Na}_{2} \mathrm{SeO}_{4}$ were set up without inoculation, and iodometric analysis of these after incubation showed that no chemical reaction between selenate and sulphite had occurred. The effect of $\mathrm{Na}_{2} \mathrm{~S}_{2} \mathrm{O}_{3}$ on growth in selenate-containing media was not studied since, after incubation at $30^{\circ}$ for $16 \mathrm{hr}$., chemical reduction of $\mathrm{Na}_{2} \mathrm{SeO}_{4}$ giving a precipitate of selenium occurred even in uninoculated cultures.

Since the formation of selenium in growing cultures containing $\mathrm{Na}_{2} \mathrm{SeO}_{4}$ might have represented a mechanism whereby cells could detoxify their medium, an attempt was made to obtain a strain able to resist $\mathrm{Na}_{2} \mathrm{SeO}_{4}$.

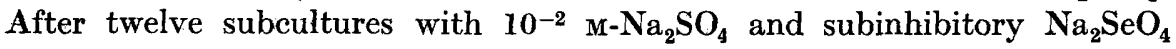


concentrations the strain had undergone no increase in its resistance to $\mathrm{Na}_{2} \mathrm{SeO}_{4}$, and the attempt was abandoned.

\section{Potassium tellurate}

The formula of potassium tellurate is sometimes written as $\mathrm{K}_{2} \mathrm{TeO}_{\mathbf{4}} \cdot \mathbf{2} \mathrm{H}_{\mathbf{2}} \mathrm{O}$, but it is now known to be a derivative of orthotelluric acid $\left(\mathrm{Te}(\mathrm{OH})_{6}\right)$ rather than of the hypothetical metatelluric acid $\left(\mathrm{H}_{2} \mathrm{TeO}_{4}\right)$. Hence it is best represented as $\mathrm{K}_{2} \mathrm{H}_{4} \mathrm{TeO}_{6}$; its structural resemblance to $\mathrm{K}_{2} \mathrm{SO}_{4}$ is consequently remote. Moreover, the alkali orthotellurates do not form real solutions, but dissolve as 'semi-colloidal' suspensions which are optically inhomogeneous (Sidgwick, 1950); it is therefore unlikely that significant amounts of the strict sulphate analogue, the $\mathrm{TeO}_{4}{ }^{\prime \prime}$ ion, exist in solutions of these salts. It was nevertheless thought desirable to test a tellurate. Potassium tellurate (British Drug Houses Ltd.) was used and assumed to have a molecular weight of $\mathbf{3 6 0}$, corresponding to its most common hydrate, $\mathrm{K}_{2} \mathrm{H}_{4} \mathbf{T e} \mathrm{O}_{6} \cdot \mathbf{3} \mathrm{H}_{2} \mathrm{O}$. 'Semi-colloidal' suspensions of this salt were destroyed by heat sterilization, and a $1 / 10$ dilution of the clear supernatant did not affect growth or sulphate reduction, so all growth tests were performed with unsterilized tellurate suspensions. Cultures in which growth occurred were examined for contaminants, but none were found.

A cell suspension of $1.12 \mathrm{mg}$. dry wt. in the Warburg manometer reduced $2.5 \times 10^{-6} \mathrm{~mol}$. $\mathrm{Na}_{2} \mathrm{SO}_{4}$ with a $-Q_{\mathrm{H}_{8}}^{\mathrm{so}}{ }^{\prime \prime}$ of $202 \mathrm{~mm} .3 / \mathrm{mg} . / \mathrm{hr}$., and this value was unaffected by $5 \times 10^{-7}$ and by $10^{-6} \mathrm{~mol}$. of potassium tellurate as a suspension. The value of $-Q_{\mathrm{H}_{a}}^{\mathrm{so} \text { " }}$ was reduced to zero by $2 \times 10^{-6} \mathrm{~mol}$. suspension and this effect was not prevented by increasing the sulphate concentration tenfold to $2.5 \times 10^{-5} \mathrm{~mol}$. $\mathrm{Na}_{2} \mathrm{SO}_{4}$. In medium $\mathrm{B}$ growth after $168 \mathrm{hr}$. with $10^{-2} \mathrm{M}-\mathrm{Na}_{2} \mathrm{SO}_{4}$ was prevented by a $2 \times 10^{-5} \mathrm{M}$ tellurate suspension but was permitted by a $10^{-5} \mathrm{M}$ suspension; a fivefold increase in the $\mathrm{Na}_{2} \mathrm{SO}_{4}$ concentration to $5 \times 10^{-2} \mathrm{M}$ did not affect these figures. Hence, though potassium tellurate inhibited both sulphate reduction and growth, this inhibition was not by way of competitive sulphate antagonism.

\section{Ammonium monofluorophosphate}

The monofluorophosphate ion, $\mathrm{PO}_{3} \mathrm{~F}^{\prime \prime}$, is analogous to sulphate in both geometry and electron distribution; monofluorophosphates have many properties in common with sulphates (Ephraim, 1934). Ammonium monofluorophosphate, $\left(\mathrm{NH}_{4}\right)_{2} \mathrm{PO}_{3} \mathrm{~F} \cdot \mathrm{H}_{2} \mathrm{O}$, prepared by the method of Lange (1929), was not reduced by resting cell suspensions of $D$. desulphuricans. The reduction of $2.5 \times 10^{-6} \mathrm{~mol}$. $\mathrm{Na}_{2} \mathrm{SO}_{4}$ was prevented by $3.75 \times 10^{-6} \mathrm{~mol}$. $\left(\mathrm{NH}_{4}\right)_{2} \mathrm{PO}_{3} \mathrm{~F}$, i.e. a molar ratio $\mathrm{PO}_{3} \mathrm{~F}^{\prime \prime}: \mathrm{SO}_{4}{ }^{\prime \prime}$ of $3: 2$; at a lower $\mathrm{PO}_{3} \mathrm{~F}^{\prime \prime}: \mathrm{SO}_{4}$ " ratio $(2: 5)$ partial inhibition occurred. This inhibition was competitive over a tenfold range of substrate and inhibitor concentrations, as the rate of hydrogen absorption was determined by the molar ratio of $\mathrm{PO}_{3} \mathrm{~F}^{\prime \prime}: \mathrm{SO}_{4}{ }^{\prime \prime}$ and not by their absolute amounts (Fig. 1). At higher levels $\left(10^{-4} \mathrm{~mol}\right.$. $\left(\mathrm{NH}_{4}\right)_{2} \mathrm{PO}_{3} \mathrm{~F}+2.5 \times 10^{-4} \mathrm{~mol}$. $\mathrm{Na}_{2} \mathrm{SO}_{4}$ ) complete inhibition of sulphate reduction was found, though the 
inhibitor:substrate ratio was still $2: 5$. This non-competitive inhibition may have been a secondary toxic action of $\left(\mathrm{NH}_{4}\right)_{2} \mathrm{PO}_{3} \mathrm{~F}$, or merely attributable to the high salt concentrations in the test media; it was not studied further.



Fig. 1

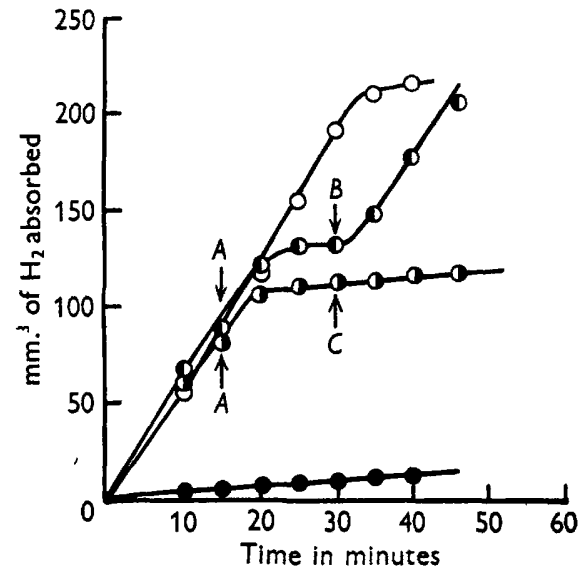

Fig. 2

Fig. 1. Competitive antagonism of sulphate reduction by monofluorophosphate with D. desulphuricans (Hildenborough). $3 \cdot 84 \mathrm{mg}$. dry wt. cells/manometer vessel. $0,2 \cdot 5 \times$ $10^{-6} \mathrm{~mol} . \mathrm{Na}_{2} \mathrm{SO}_{4} ; \ominus, 5 \times 10^{-6} \mathrm{~mol} . \mathrm{Na}_{2} \mathrm{SO}_{4}+2 \times 10^{-6} \mathrm{~mol} .\left(\mathrm{NH}_{4}\right)_{2} \mathrm{PO}_{3} \mathrm{~F} ; \Theta, 10^{-6} \mathrm{~mol}$. $\mathrm{Na}_{2} \mathrm{SO}_{4}+4 \times 10^{-6} \mathrm{~mol}$. $\left(\mathrm{NH}_{4}\right)_{2} \mathrm{PO}_{3} \mathrm{~F} ; \mathrm{O}, 2.5 \times 10^{-5} \mathrm{~mol}$. $\mathrm{Na}_{2} \mathrm{SO}_{4}+10^{-5} \mathrm{~mol} .\left(\mathrm{NH}_{4}\right)_{2} \mathrm{PO}_{3} \mathrm{~F}$; , no substrate.

Fig. 2. Non-competitive monofluorophosphate antagonism by sulphite with $D$. desulphuricans (Hildenborough), $2 \cdot 74 \mathrm{mg}$. dry wt. cells/manometer vessel. $\bigcirc, 2 \cdot 5 \times 10^{-6} \mathrm{~mol}$. $\mathrm{Na}_{2} \mathrm{SO}_{4} ; O$, no substrate; $0,2.5 \times 10^{-6} \mathrm{~mol}$. $\mathrm{Na}_{2} \mathrm{SO}_{4}$ added at start, then $3.75 \times 10^{-6} \mathrm{~mol}$. $\left(\mathrm{NH}_{4}\right)_{2} \mathrm{PO}_{3} \mathrm{~F}$ at $A$, followed by $2.5 \times 10^{-6} \mathrm{~mol} . \mathrm{Na}_{2} \mathrm{SO}_{3}$ at $B ; 0,2.5 \times 10^{-6} \mathrm{~mol} . \mathrm{Na}_{2} \mathrm{SO}_{4}$ added at start, then $3.75 \times 10^{-6} \mathrm{~mol}$. $\left(\mathrm{NH}_{4}\right)_{2} \mathrm{PO}_{3} \mathrm{~F}$ at $A$, followed by $2.5 \times 10^{-6} \mathrm{~mol}$. $\mathrm{Na}_{2} \mathrm{SO}_{4}$ at $C$.

Sulphite was a non-competitive antagonist of the inhibition of hydrogen absorption caused by $\left(\mathrm{NH}_{4}\right)_{2} \mathrm{PO}_{3} \mathrm{~F}$ in the presence of $\mathrm{Na}_{2} \mathrm{SO}_{4}$. The absorption of hydrogen consequent on the reduction of $2.5 \times 10^{-6} \mathrm{~mol}$. $\mathrm{Na}_{2} \mathrm{SO}_{4}$ was prevented by addition of $3.75 \times 10^{-6} \mathrm{~mol}$. $\left(\mathrm{NH}_{4}\right)_{2} \mathrm{PO}_{3} \mathrm{~F}$. Addition of a molar concentration of $\mathrm{Na}_{2} \mathrm{SO}_{3}$ equal to that of the $\mathrm{Na}_{2} \mathrm{SO}_{4}$ originally present permitted the resumption of hydrogen absorption, whereas addition of an equivalent molar $\mathrm{Na}_{2} \mathrm{SO}_{4}$ concentration did not (Fig. 2). There was a time lag of several minutes after addition of $\left(\mathrm{NH}_{4}\right)_{2} \mathrm{PO}_{3} \mathrm{~F}$ before sulphate reduction ceased, suggesting that the $\mathrm{PO}_{3} \mathrm{~F}^{\prime \prime}$ ion was slow to penetrate the cell and reach the sulphate-reducing enzyme. No such lag was observed with $\mathrm{Na}_{2} \mathrm{SeO}_{4} \cdot \mathrm{Na}_{2} \mathrm{~S}_{2} \mathrm{O}_{3}$ was also a noncompetitive $\left(\mathrm{NH}_{4}\right)_{2} \mathrm{PO}_{3} \mathrm{~F}$ antagonist, being reduced in the presence of sufficient $\left(\mathrm{NH}_{4}\right)_{2} \mathrm{PO}_{3} \mathrm{~F}$ to prevent the reduction of 3 times the molar concentration of $\mathrm{Na}_{2} \mathrm{SO}_{4}$.

$\left(\mathrm{NH}_{4}\right)_{2} \mathrm{PO}_{3} \mathrm{~F}$ also acted as a competitive sulphate antagonist in the growth of D. desulphuricans (Table 4); a molar $\mathrm{PO}_{3} \mathrm{~F}^{\prime \prime}: \mathrm{SO}_{4}{ }^{\prime \prime}$ ratio between $2: 1$ and $1: 1$ was needed to prevent visible growth in medium B. Half growth occurred with a $\mathrm{PO}_{3} \mathrm{~F}^{\prime \prime}: \mathrm{SO}_{4}{ }^{\prime \prime}$ ratio between $1: 1$ and $1: 2$. Table 4 also records that both 
$\mathrm{Na}_{2} \mathrm{SO}_{3}$ and $\mathrm{Na}_{2} \mathrm{~S}_{2} \mathrm{O}_{3}$ acted as non-competitive antagonists of $\left(\mathrm{NH}_{4}\right)_{2} \mathrm{PO}_{3} \mathrm{~F}$. Growth with these substrates occurred at all $\left(\mathrm{NH}_{4}\right)_{2} \mathrm{PO}_{3} \mathrm{~F}$ concentrations tested; at the highest test concentration, $\mathbf{1 0}^{-1} \mathrm{M}$, growth was delayed in both cases.

Table 4. Monofluorophosphate-sulphate antagonism in groveth of

D. desulphuricans (Hildenborough) in medium $\boldsymbol{B}$

Cultures $(5 \mathrm{ml}$.) were incubated for $162 \mathrm{hr}$. and inspected.

\begin{tabular}{|c|c|c|}
\hline $\begin{array}{c}\mathrm{Na}_{2} \mathrm{SO}_{4} \text { conc. } \\
\text { (M) }\end{array}$ & $\begin{array}{l}\text { Least conc. } \\
\text { of }\left(\mathrm{NH}_{4}\right)_{2} \mathrm{PO}_{3} \mathrm{~F} \\
\text { preventing } \\
\text { growth }(\mathrm{M})\end{array}$ & $\begin{array}{c}\text { Greatest conc. } \\
\text { of }\left(\mathrm{NH}_{4}\right)_{2} \mathrm{PO}_{3} \mathrm{~F} \\
\text { permitting } \\
\text { growth (M) }\end{array}$ \\
\hline $\begin{array}{c}10^{-2} \\
2 \times 10^{-2} \\
5 \times 10^{-2}\end{array}$ & $\begin{array}{c}2 \times 10^{-2} \\
4 \times 10^{-2} \\
10^{-1}\end{array}$ & $\begin{array}{c}10^{-2} \\
2 \times 10^{-2} \\
5 \times 10^{-2}\end{array}$ \\
\hline$\underset{10^{-2}}{\mathrm{Na}_{2} \mathrm{SO}_{3} \text { conc. }(\mathrm{M}}$ & $>10^{-1}$ & $>10^{-1}$ \\
\hline $\begin{array}{c}\mathrm{Na}_{2} \mathrm{~S}_{2} \mathrm{O}_{3} \text { conc. }(\mathrm{M} \\
10^{-2}\end{array}$ & $>10^{-1}$ & $>10^{-1}$ \\
\hline
\end{tabular}

Potassium chromate

An early report (Chemistry Research, 1948) that $\mathrm{K}_{2} \mathrm{CrO}_{4}$ inhibited the growth of sulphate-reducing bacteria, and that its effect was antagonized by ferrous ions, did not discuss whether it was a sulphate antagonist, though the chromates and sulphates are analogues in Group VI of the Periodic Table.

In the Warburg manometer $\mathrm{K}_{2} \mathrm{CrO}_{4}$ was a powerful inhibitor of sulphate reduction, and $2.5 \times 10^{-7} \mathrm{~mol} . \mathrm{K}_{2} \mathrm{CrO}_{4}$ prevented the reduction of $2.5 \times 10^{-6}$ mol. $\mathrm{Na}_{2} \mathrm{SO}_{4}$ and of $2.5 \times 10^{-5} \mathrm{~mol} . \mathrm{Na}_{2} \mathrm{SO}_{4}$. Partial inhibition of sulphate reduction was obtained by $2.5 \times 10^{-8} \mathrm{~mol} . \mathrm{K}_{2} \mathrm{CrO}_{4}$. The rate of sulphate reduction in these conditions was independent of the sulphate concentration over a tenfold range (Table 5).

Table 5. Effect of chromate on reduction of sulphate. Hydrogen absorption by cell suspensions of $\mathrm{D}$. desulphuricans (Hildenborough)

Vessels contained $2.5 \mathrm{ml}$. fluid at $37^{\circ}$ and $2 \cdot 16 \mathrm{mg}$. dry wt. cells

$\begin{array}{ccc}\mathrm{Na}_{8} \mathrm{SO}_{4} & \mathrm{~K}_{2} \mathrm{CrO}_{4} & -Q_{\mathrm{H}_{2}} \\ \left(\mathrm{~mol} \times 10^{-6}\right) & \left(\mathrm{mol} \times 10^{-6}\right) & (\mathrm{mm} . \mathbf{3} / \mathrm{mg} \cdot / \mathrm{hr} .) \\ 2.5 & - & 490 \\ 2.5 & 0.025 & 276 \\ 25 & 0.025 & 276 \\ 2.5 & 0.25 & 0 \\ 25 & 0.25 & 0 \\ - & - & 5.5\end{array}$

Experiments on the growth in medium $\mathrm{B}$ are reported in Table 6. Visible growth with $10^{-2} \mathrm{M}-\mathrm{Na}_{2} \mathrm{SO}_{4}$ was prevented by $\mathrm{K}_{2} \mathrm{CrO}_{4}$ concentrations in the region of $10^{-4} \mathrm{M}$. This figure was unaltered by a fivefold increase in the sulphate concentration; thus chromate was not a competitive antagonist of sulphate reduction. 
Table 6. Inhibition by chromate of growth of $\mathrm{D}$. desulphuricans (Hildenborough) in medium $B$

Cultures $(5 \mathrm{ml}$.) were incubated $144 \mathrm{hr}$. and inspected.

\begin{tabular}{|c|c|c|}
\hline$\underset{(M)}{\mathrm{Na}_{2} \mathrm{SO}_{4} \text { conc. }}$ & $\begin{array}{l}\text { Least conc. } \\
\text { of } \mathrm{K}_{2} \mathrm{CrO}_{4} \\
\text { preventing } \\
\text { growth (M) }\end{array}$ & $\begin{array}{c}\text { Greatest conc. } \\
\text { of } \mathrm{K}_{2} \mathrm{CrO}_{4} \\
\text { permitting } \\
\text { growth (M) }\end{array}$ \\
\hline $\begin{array}{c}10^{-2} \\
5 \times 10^{-2}\end{array}$ & $\begin{array}{l}10^{-4} \\
10^{-4}\end{array}$ & $\begin{array}{l}5 \times 10^{-5} \\
5 \times 10^{-5}\end{array}$ \\
\hline
\end{tabular}

Other analogues of sulphate

The perchlorate ion and its homologues in Group VII of the Periodic Table are in a broad sense analogues of the sulphate ion, though they have only one charge. As an example of this group potassium perchlorate $\left(\mathrm{KClO}_{4}, \mathrm{British}\right.$ Drug Houses Ltd.) was tested. Other analogues of sulphate used here involved the replacement of oxygen atoms in the ion by basic groups, and were of three main classes: (i) alkyl and aryl sulphonic acids, in which one oxygen atom is replaced, e.g. sodium methanesulphonate $\left(\mathrm{NaO} . \mathrm{SO}_{2} \mathrm{CH}_{3}\right.$; synthetic), sodium $\beta$-hydroxyethanesulphonate $\left(\mathrm{NaO} . \mathrm{SO}_{2} \mathrm{CH}_{2} \mathrm{CH}_{2} \mathrm{OH}\right.$; synthetic), and sodium benzenesulphonate ( $\mathrm{NaO} . \mathrm{SO}_{2} \phi$; British Drug Houses Ltd.); (ii) sulphones, in which two oxygen atoms are substituted, e.g., dimethylsulphone $\left(\left(\mathrm{CH}_{3}\right)_{2} \mathrm{SO}_{2}\right.$; synthetic); (iii) compounds such as sulphamic acid and nitrosylsulphuric acid, in which an oxygen atom is exchanged for a basic inorganic group; represented by ammonium sulphamate $\left(\mathrm{NH}_{4} \cdot \mathrm{SO}_{3} \mathrm{NH}_{2} ;\right.$ Baird and Tatlock Ltd.). Partial esterification of the sulphate ion gives compounds having a structural resemblance to sulphate; as an example sodium ethylsulphate $\left(\mathrm{Na}\left(\mathrm{C}_{2} \mathrm{H}_{5}\right) \mathrm{SO}_{4}\right.$; synthetic) was tested.

All these compounds were tested with resting suspensions in the Warburg manometer in equimolecular proportion to the $\mathrm{Na}_{2} \mathrm{SO}_{4}$ added; $2.5 \times 10^{-6} \mathrm{~mol}$. of substrate and test material were used. In no case was the rate of sulphate reduction affected by these materials (Table 7), so the findings were checked by testing these compounds at ten times the equivalent molar sulphate concentration, using $2.5 \times 10^{-6} \mathrm{~mol}$. $\mathrm{Na}_{2} \mathrm{SO}_{4}$ and $2.5 \times 10^{-5} \mathrm{~mol}$. test material. The only compound to show activity in these tests was $\mathrm{KClO}_{4}$, which depressed the reduction rate by about $85 \%$. The diminished rate of reduction was independent of the $\mathrm{Na}_{2} \mathrm{SO}_{4}$ concentration over a tenfold range, however, indicating that this was not competitive sulphate antagonism (Table 7).

\section{Acridinium dye 914}

Since dye 914 (Imperial Chemical Industries Ltd.) has a growth-inhibitory effect on $D$. desulphuricans in crude cultures (Rogers, 1940, 1945) it was desirable to find out whether it acted by interference with sulphate metabolism. A concentration of dye about ten times that required to prevent growth, however, did not significantly affect sulphate reduction. A cell suspension of $2.9 \mathrm{mg}$. dry wt. reduced $2.5 \times 10^{-6}$ mol. $\mathrm{Na}_{2} \mathrm{SO}_{4}$ with a $-Q_{\mathrm{H}_{8}}{ }^{\prime \prime}$ of $236 \mathrm{~mm} .{ }^{3} /$ $\mathrm{mg}$. $/ \mathrm{hr}$.; with $250 \mu \mathrm{g}$. dye the quotient was $212 \mathrm{~mm} .3 / \mathrm{mg} . / \mathrm{hr}$. 
Table 7. Tests of various potential inhibitors of sulphate reduction. Hydrogen absorption by cell suspensions of $\mathrm{D}$. desulphuricans (Hildenborough)

$\mathrm{Na}_{2} \mathrm{SO}_{4}$
$\left(\mathrm{~mol}^{\circ} \times 10^{-6}\right)$
$2 \cdot 5$
$2 \cdot 5$
$2 \cdot 5$
$2 \cdot 5$
$2 \cdot 5$
$2 \cdot 5$
$2 \cdot 5$
$2 \cdot 5$
$2 \cdot 5$
$2 \cdot 5$
$2 \cdot 5$
$2 \cdot 5$
$2 \cdot 5$
$2 \cdot 5$
$2 \cdot 5$
$2 \cdot 5$
$2 \cdot 5$
$2 \cdot 5$
2.5
$\mathbf{2 5}$

Vessels contained $2.5 \mathrm{ml}$. fluid at $37^{\circ}$.

\begin{tabular}{|c|c|c|}
\hline $\begin{array}{l}\text { Compound tested } \\
\left(\mathrm{mol} . \times 10^{-6}\right)\end{array}$ & $\begin{array}{c}\text { Cells } \\
\text { (mg. dry wt.) }\end{array}$ & $\begin{array}{c}-Q_{\mathrm{H}_{2}} \\
(\mathrm{~mm} \cdot \mathbf{3} / \mathrm{mg} \cdot / \mathrm{hr} .)\end{array}$ \\
\hline 一 & $2 \cdot 2$ & 210 \\
\hline $\mathrm{NaO} . \mathrm{SO}_{2} \cdot \mathrm{CH}_{3} ; 2.5$ & $2 \cdot 2$ & 202 \\
\hline $\mathrm{NaO} \cdot \mathrm{SO}_{2} \cdot \mathrm{C}_{2} \mathrm{H}_{4} \mathrm{OH} ; 2 \cdot 5$ & $2 \cdot 2$ & 205 \\
\hline - & $2 \cdot 4$ & 180 \\
\hline $\mathrm{NH}_{4} \mathrm{SO}_{3} \mathrm{NH}_{2} ; 2.5$ & $2 \cdot 4$ & 180 \\
\hline $\mathrm{NaO} . \mathrm{SO}_{2} \phi ; 2.5$ & $\mathbf{2 \cdot 4}$ & 180 \\
\hline 一 & $1 \cdot 84$ & 260 \\
\hline$\left(\mathrm{CH}_{3}\right)_{2} \mathrm{SO}_{2} ; 2 \cdot 5$ & $1 \cdot 84$ & 260 \\
\hline 一 & $1 \cdot 0$ & 735 \\
\hline$\left(\mathrm{CH}_{3}\right)_{2} \mathrm{SO}_{2} ; 25$ & $1 \cdot 0$ & 790 \\
\hline $\mathrm{Na}\left(\mathrm{C}_{2} \mathrm{H}_{5}\right) \mathrm{SO}_{4} ; 25$ & $\mathbf{1} \cdot \mathbf{0}$ & 732 \\
\hline 一 & $0 \cdot 67$ & 331 \\
\hline $\mathrm{HN}_{4} \cdot \mathrm{SO}_{3} \mathrm{NH}_{2} ; 25$ & 0.67 & 339 \\
\hline $\mathrm{NaO} . \mathrm{SO}_{2} \phi ; 25$ & $0 \cdot 67$ & 325 \\
\hline - & 0.59 & 570 \\
\hline $\mathrm{NaO} \cdot \mathrm{SO}_{2} \cdot \mathrm{CH}_{3} ; 25$ & 0.59 & 580 \\
\hline 一 & $1 \cdot 62$ & 310 \\
\hline $\mathrm{NaO} . \mathrm{SO}_{2} \cdot \mathrm{C}_{2} \mathrm{H}_{4} \mathrm{OH} ; 25$ & $1 \cdot 62$ & 320 \\
\hline $\mathrm{KClO}_{4} ; 25$ & $1 \cdot 62$ & 59 \\
\hline $\mathrm{KClO}_{4} ; 25$ & $1 \cdot 62$ & 61 \\
\hline- & $1 \cdot 62$ & 2 \\
\hline
\end{tabular}

The inhibitory effect of dye 914 on growth was also unaffected by the $\mathrm{Na}_{2} \mathrm{SO}_{4}$ concentration. Visible growth was prevented by between 8 and $10 \mu \mathrm{g}$. dye/ml. in medium $\mathrm{B}$ containing either $10^{-2} \mathrm{M}-\mathrm{Na}_{2} \mathrm{SO}_{4}$ or five times this amount. Postgate $(1951 a)$ showed that peptone and yeast extract contained growthpromoting substances for this strain of $\boldsymbol{D}$. desulphuricans, but the resistance of cells to dye 914 was not affected by the presence or absence of these supplements. The resistance of the cells remained at $c .10 \mu \mathrm{g} . \mathrm{dye} / \mathrm{ml}$. whether they were grown in medium A or in Starkey's (1938) medium containing only lactic acid and inorganic salts.

The possibility, mentioned by Rogers (1940), that dye-resistant strains might appear in low concentrations of dye 914 was confirmed. After six passages in medium $\mathbf{A}$ with subinhibitory amounts of dye the resistance had increased at least twenty-fold (Table 8). As in all this work, the inoculum size was $1 \mu \mathrm{g}$. dry wt. cells $/ 5 \mathrm{ml}$. culture at each subculture.

\section{DISCUSSION}

The findings with dye 914 require little discussion. Its inhibitory action was not correlated with the peculiar metabolism of $D$. desulphuricans; it was not demonstrably related to the process of sulphate reduction and was unrelated to the need of this organism for certain substances in peptone and yeast extract. Resistance to the dye was acquired readily, but there is no evidence from this work to indicate whether the process was 'adaptational' or 'mutational'. 
It is now well known that structural analogues of metabolites often inhibit the utilization of metabolites in a competitive manner. Since the first demonstration of this point (Woods, 1940) the concept of metabolite antagonism has been widely applied in the search for inhibitors of therapeutic value. Metabolite analogues have most often been selected to antagonize the utilization of growth factors or amino-acids : substances required only in small amounts but whose presence is essential. Thus the growth of an organism can be prevented by small amounts of this kind of anti-metabolite. In the present case, however, sulphate is required by $D$. desulphuricans in relatively large amounts since sulphate reduction is the main energy-yielding reaction for growth. The

Table 8. 'Training' D. desulphuricans (Hildenborough) to resist dye 914 in medium $B$

\begin{tabular}{|c|c|c|c|}
\hline $\begin{array}{c}\text { Serial } \\
\text { no. of } \\
\text { subculture }\end{array}$ & $\begin{array}{c}\text { Interval } \\
\text { between } \\
\text { subcultures } \\
\text { (days) }\end{array}$ & $\begin{array}{l}\text { Highest } \\
\text { concentration } \\
\text { of dye } \\
\text { permitting } \\
\text { growth } \\
(\mu \mathrm{g} . / \mathrm{ml} .)\end{array}$ & $\begin{array}{c}\text { Lowest } \\
\text { concentration } \\
\text { of dye } \\
\text { preventing } \\
\text { growth } \\
(\mu \mathrm{g} . / \mathrm{ml} .)\end{array}$ \\
\hline 1 & - & 8 & 10 \\
\hline 2 & 4 & 8 & 10 \\
\hline $\mathbf{3}$ & 9 & 10 & 12 \\
\hline 4 & 12 & 12 & - \\
\hline 5 & 7 & 16 & - \\
\hline 6 & 3 & 100 & 200 \\
\hline
\end{tabular}

competitive inhibition of sulphate-hydrogenase by selenate and monofluorophosphate is thus more strictly analogous to the inhibition of a catabolic reaction, such as the competitive inhibition of succinic dehydrogenase by malonate (Hopkins, Morgan \& Lutwak-Mann, 1938), rather than to the inhibitions involving competition with trace factors. Woods (1949) pointed out that competitive antagonism suggests that the anti-metabolite inhibitor is adsorbed at the surface of the enzyme which uses the metabolite, and that a substance which overcomes the effect of the inhibitor in a non-competitive manner may represent one of the normal products of the inhibited reaction. Nimmo-Smith, Lascelles \& Woods (1948) showed that this occurred with Streptobacterium plantarum: pteroylglutamic acid was a non-competitive sulphanilamide antagonist and sulphanilamide interfered competitively with its synthesis from $p$-aminobenzoic acid by the organism. The effect of sulphite in overcoming the inhibitory effects of selenate and monofluorophosphate on D. desulphuricans, reported here, was probably a similar instance; sulphite was probably a normal intermediate in the reduction of sulphate. On the other hand, the case of thiosulphate is not so clear, since, though it was a non-competitive antagonist of selenate and monofluorophosphate inhibition, there is evidence, from the rate at which cells reduce it, that it is not a normal intermediate in sulphate reduction (Postgate, $1951 b$ ). It is possible that it acted as a non-competitive antagonist because it was reduced by a mechanism different from normal sulphate reduction.

That the sulphur-containing compounds methionine, cysteine and gluta- 
thione had no anti-selenate effect with $D$. desulphuricans contrasts with the findings of Fels \& Cheldelin $(1948,1949 a, b)$ with yeast and Esch. coli already described. The difference in behaviour is probably attributable to the fact that sulphate-reduction is quantitatively most important as an energy-yielding reaction for $D$. desulphuricans. The reactions corresponding to those studied by Fels \& Cheldelin, leading to the synthesis of sulphur containing amino-acids and peptides, play a quantitatively small part in the sulphate metabolism of this genus, and contribute negligibly to the total turnover of sulphate.

Competitive metabolite antagonism is often pictured as a simple physicochemical process in which no change occurs to the inhibitor; it merely displaces the metabolite from its enzyme, and both thermodynamic and kinetic treatments of competitive interrelations have been put forward based on this assumption (Wyss, 1941; Klotz, 1944; Klotz \& Gutmann, 1945). However, Hurd-Karrer (1937, 1938) showed that selenium was incorporated in the tissues of partially selenate-inhibited wheat plants, and in the present work there is little doubt that selenate at subinhibitory concentrations was reduced to selenium, though this reduction did not interfere with the competitive nature of selenate inhibition. It is unlikely that the normal sulphate-utilizing enzyme was involved in selenate reduction, since deposition of selenium occurred only at levels of selenate which caused partial inhibition; no deposition of selenium by completely inhibited cells was ever observed, either in growth or manometric experiments. Moreover, if selenate were attacked directly, it is curious that the 'training' process to which the organisms were subjected did not give rise to a strain better able to reduce selenate and thus of greater selenate resistance. Selenate is readily reduced by chemical means, and it is probable that the deposition of selenium was a side-reaction involving the reaction of selenate with some reducing agent produced by actively metabolizing cells.

The activity of a metabolite analogue depends not only on its steric resemblance to the metabolite, but also on its resemblance in electron distribution. Bell \& Roblin (1942) correlated the inhibitory action of the sulphonamide drugs with their electronic resemblance to $p$-aminobenzoic acid as reflected in their acid dissociation constants. By a study of anti-tryptophan substances in which the double bonds of the aromatic indole system were stabilized in various positions, Fildes \& Rydon (1947) obtained strong indications of the form in which the tryptophan molecule combined with its utilizing enzyme in Bact. typhosum. Inspection of the structures of the compounds tested in the present work (Fig. 3) shows that two charges on the ion were necessary for interaction with the sulphate-utilizing enzyme; all the singly-charged sulphate analogues were unable to affect the enzyme. Moreover, provided the requirements of charge distribution were satisfied, an ion such as $\mathrm{PO}_{3} \mathrm{~F}^{\prime \prime}$, which has an atomic constitution very different from sulphate, was able to interact with the sulphate-utilizing enzyme. The inactivity of tellurate as a sulphate antagonist may be attributed to the fact that the $\mathrm{TeO}_{4}{ }^{\prime \prime}$ ion was probably unstable in the test conditions.

There is no obvious reason why chromate should have been inactive, as it satisfies the requirement for charge, and its general shape-a symmetrical 
tetrahedral ion-resembles that of sulphate. It had, however, a strong nonspecific toxic effect on cells of $\boldsymbol{D}$. desulphuricans even at low concentrations, and that may have masked any competitive activity. Alternatively, as the action of monofluorophosphate on sulphate reduction was delayed, presumably owing to slow penetration of inhibitor to enzyme, and since the chromate ion was the largest of the simple divalent ions tested, chromate may have been

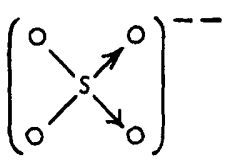

Sulphate

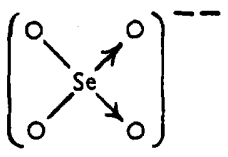

Selenate

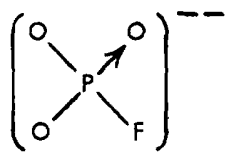

Monofluorophosphate

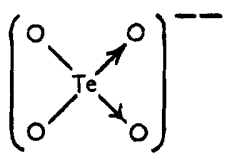

metaTellurate

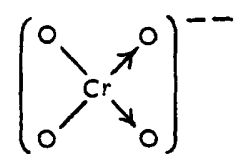

Chromate

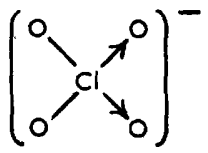

Perchlorate

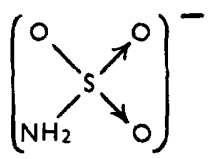

Sulphamate

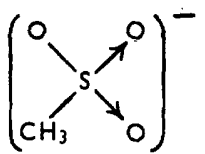

Methanesulphonate

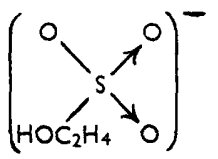

$\boldsymbol{\beta}$-Hydroxyethanesulphonate<smiles>CO[Si](O)(O)O</smiles>

Benzenesulphonate<smiles>CCOS(O)(O)(O)(O)OC</smiles>

Ethylsulphate<smiles>C[As](C)(C)O</smiles>

Dimethylsulphone

Fig. 3. The chemical structures of some analogues of the sulphate ion.

too large to reach the enzyme at all. The diameters of the sulphate, selenate and monofluorophosphate ions are similar, whereas the diameter of the chromate ion is considerably greater.

These studies have mainly been concerned with antagonism of the utilization of an inorganic anion by other anions; most studies in the field of metabolite antagonism have been restricted to antagonists of complex organic molecules, though Macleod \& Snell (1948) demonstrated antagonisms between alkali metal cations in the growth of lactic bacteria. The molar concentration ratios permitting a half-maximal rate of sulphate reduction illustrate the remarkably high specific activities of the two competitive inhibitors studied here. For the antagonism of $p$-aminobenzoic utilization by sulphonamides, for example, molar concentrations several hundred times that of the $p$-aminobenzoic acid may be required for half-inhibition, and even with the highly active folic acid antagonist, aminopterin, a molar ratio of inhibitor to metabolite less than $1: 1$ is rare, though it occurs with Streptococcus faecalis $\mathbf{R}$ at high concentrations of metabolite and antagonist (Franklin, Belt, Stokstad \& Jukes, 1949). In the present work, however, a $\mathrm{Na}_{2} \mathrm{SeO}_{4}: \mathrm{Na}_{2} \mathrm{SO}_{4}$ ratio of $1: 10$ completely inhibited sulphate reduction, one of about 1:50 permitted a half-maximal reduction 
rate, and an $\left(\mathrm{NH}_{4}\right)_{2} \mathrm{PO}_{3} \mathrm{~F}: \mathrm{Na}_{2} \mathrm{SO}_{4}$ ratio of about $2: 5$ gave a half-maximal rate. Selenate thus showed a remarkably high specific activity, and though the activity of monofluorophosphate was but a twentieth of this, it was nevertheless high for a competitive metabolite antagonist. It is possible that selenate and monofluorophosphate are concentrated inside the cell by conversion to a non-diffusible active form, thus becoming highly active at their site of action. On the other hand, if the effect of these inhibitors was to interfere with sulphate reduction by a simple physico-chemical process, by competitive reaction with or adsorption on the sulphate-reducing enzyme, then this enzyme must have had a greater chemical affinity for the inhibitors than for its normal substrate. The free energy of formation of the inhibitor-enzyme complex must have been greater, and in the case of selenate, very much greater, than the free energy of formation of the sulphate-enzyme complex.

The author wishes to thank Dr G. A. Maw for specimens of methanesulphonate and $\beta$-hydroxyethanesulphonate; Mr H. D. Hollingsworth for a specimen of dimethylsulphone; Imperial Chemical Industries Ltd. for a specimen of acridinium dye 914; Dr B. C. Saunders for a preliminary sample of ammonium monofluorophosphate. He is also indebted to Mr W. Ryan for preparing subsequent samples of monofluorophosphate, to Miss J. P. Cowne for the preparation of sodium ethylsulphate and to Mr K. R. Butlin for his advice and interest. This paper is published by permission of the Director, Chemical Research Laboratory.

\section{REFERENCES}

Allen, L. A. (1949). The effect of nitro-compounds and some other substances on the production of hydrogen sulphide by sulphate-reducing bacteria in sewage. Proc. Soc. appl. Bact. no. 2, 26.

Bell, P. H. \& Roblin, R. O. (1942). A theory of the relation of structure to activity of sulphanilamide type compounds. J. Amer. chem. Soc. 64, 2905.

Bunker, H. J. (1936). A Review of the Physiology and Biochemistry of the Sulphur Bacteria. London: H.M. Stat. Office.

Bunker, H. J. (1939). Microbiological experiments in anaerobic corrosion. J. Soc. chem. Ind., Lond., 58, 93.

BUNKER, H. J. (1942). The control of bacterial sulphate reduction by regulation of the hydrogen-ion concentration. Proc. Soc. agric. Bact. no. 1, 1.

Butun, K. R. (1949). Some malodorous activities of sulphate-reducing bacteria. Proc. Soc. appl. Bact. no. 2, 39.

Butlin, K. R. \& Vernon, W. H. J. (1949). Underground corrosion of metals; causes and prevention. J. Inst. Water Engineers, p. 627.

Chemistry Research, 1938-1946. London: H.M. Stat. Office.

Chemistry Research, 1947. London: H.M. Stat. Office.

Chemistry Research, 1948. London: H.M. Stat. Office.

Chemistry Research, 1949. London: H.M. Stat. Office.

Ephraim, F. (1934). A Text-Book of Inorganic Chemistry, and ed., p. 693. London: Gurney and Jackson.

Fels, I. G. \& Cheldelin, V. H. (1948). Methionine in selenium poisoning. J. biol. Chem. 176, 819.

Fels, I. G. \& Cheldelin, V. H. (1949a). Selenate inhibition studies. III. The reversal of selenate inhibition in $E$. coli. Arch. Biochem. 22, 323.

Fels, I. G. \& Cheldelin, V. H. (1949b). Selenate inhibition studies. III. The role of sulphate in selenate toxicity in yeasts. Arch. Biochem. 22, 402. 
Fildes, P. \& Rydon, H. N. (1947). Inhibition of growth of Bact. typhosum by methyl derivatives of indole and tryptophan. Brit. J. exp. Path. 28, 211.

Franklin, A. L., Belt, M., Stokstad, E. L. R. \& Jukes, T. H. (1949). Biological studies with 4-amino-10-methylpteroylglutamic acid. J. biol. Chem. 177, 621 .

HadLey, R. F. (1943). The Influence of Sporovibrio desulphuricans on the Current and Potential Behaviour of Corroding Iron. Philadelphia: Susquehanna Pipe Line Co., U.S.A.

Hopkins, F. G., Morgan, E. J. \& Lutwak-Mann, C. (1938). The influence of thiol groups on the activity of dehydrogenases. Biochem. J. 32, 1829.

Hurd-Karrer, A. M. (1937). Comparative toxicity of selenates and selenites to wheat. Amer. J. Bot. 24, 720.

Hurd-Karrer, A. M. (1938). Relation of sulphate to selenium absorption in plants. Amer. J. Bot. 25, 666.

KLotz, I. M. (1944). 'The mode of action of sulphonamides. J. Amer. chem. Soc. 66, 459.

Klotz, I. M. \& Gutmann, H. R. (1945). The mode of action of sulphonamides. Dissociation constants of the enzyme-drug complex. J. Amer. chem. Soc. 67, 558.

Lange, W. (1929). Über die Difluorphosphorsäure und ihre der Perchlorsäure ähnliche Salzbildung. Ber. dtsch. chem. Ges. 62, 791.

Macleod, R. A. \& SNeld, E. E. (1948). The effect of related ions on the potassium requirement of lactic acid bacteria. J. biol. Chem. 176, 39.

Nimmo-Smith, R. H., LAscelles, J. \& Woods, D. D. (1948). The synthesis of folic acid by Streptobacterium plantarum and its inhibition by sulphonamides. Brit. J. exp. Path. 29, 264.

Postgate, J. R. (1949). Competitive inhibition of sulphate reduction by selenate. Nature, Lond., 164, 670.

Postgate, J. R. (1951 a). On the nutrition of Desulphovibrio desulphuricans. J. gen. Microbiol. 5, 714.

Postgate, J. R. (1951b). The reduction of various sulphur compounds by Desulphovibrio desulphuricans. J. gen. Microbiol. 5, 725.

Rogers, T. H. (1940). The inhibition of sulphate-reducing bacteria by dyestuffs. J. Soc. chem. Ind., Lond., 59, 34.

Rogers, T. H. (1945). The inhibition of sulphate-reducing bacteria by dyestuffs. Part II. Practical applications in cable storage tanks, and gas holders. J. Soc. chem. Ind., Lond., 64, 292.

Sidgwick, N. V. (1950). The Chemical Elements and their Compounds, p. 984. Oxford University Press.

Starkey, R. L. (1938). A study of spore formation and other morphological characteristics of Vibrio desulphuricans. Arch. Microbiol. 9, 268.

Starkey, R. L. (1947). Sulphate reduction and the anaerobic corrosion of iron. Antonie van Leeurenhoek J. Microbiol. Serol. 12, 193.

Starkey, R. L. \& Wight, K. M. (1945). Anaerobic Corrosion of Iron in Soil. Final report of the American Gas Ass. Iron Corrosion Res. Fellowship, Amer. Gas. Ass., N.Y.

Wolzogen Kuhr, C. A. H. von \& Vlugt, L. S. van der (1934). The graphitization of cast iron as an electro-biochemical process in anaerobic soils. Water, 18, 147.

Woons, D. D. (1940). The relation of $p$-aminobenzoic acid to the mechanism of the action of sulphanilamide. Brit. J. exp. Path. 21, 74.

Woons, D. D. (1949). Contribution to 'A discussion on the antibiotic activity of growth factor analogues.' Proc. Roy. Soc. B, 136, 147.

Wyss, O. (1941). The nature of sulphonamide inhibition. Proc. Soc. exp. Biol., N.Y., $48,122$. 